\title{
Ethno Archaeology as Embedded History: The Kerala Experience
}

\author{
Dr. Manjula Poyil \\ Assistant Professor \& Head \\ Department of History \\ Kannur University, Kerala, India \\ manjulap@kannuruniv.ac.in
}

\begin{abstract}
Ethno archaeology is a branch of archaeology developed in Western world and ethno archaeologist began to use ethnographic parallels for explaining archaeological evidences from 1950's onwards. Ethnoarchaeology essentially involves archaeologists living with peoples still generating the sort of residues found in the archaeological record and then using their modern data to suggest how things may have happened in the past.

Keywords: -Ethno Archaeology, Kurumbrar, Kerala, Everyday Life

Ethno archaeology is a branch of archaeology developed in Western world and ethno archaeologist began to use ethnographic parallels for explaining archaeological evidences from 1950's onwards. The word ethnoarchaeology is derived from the Greek word ethnos meaning race, ethno refers to a people or culture, thus the term ethnoarchaeology. Specialists in this field immerse themselves in other people's lives-especially those of people whose way of life is more comparable to that of the prehistoric or medieval past than to modern life ${ }^{1}$. Ethnoarchaeology essentially involves archaeologists living with peoples still generating the sort of residues found in the archaeological record and then using their modern data to suggest how things may have happened in the past. Ethno -archaeology contributes directly towards historical reconstruction when conventional historical sources are lacking or
\end{abstract}


when other forms of preserved traditions require substantial support. Hence, it helps in reducing the mythical notion about the ancient ways of life, particularly the lifestyle of the pre-historic people ${ }^{2}$.

The term Ethnoarchaeology was coined by Jess Fewkes in his article Tusayan Migration Tradition. ${ }^{3}$ Fewkes try to trace contemporary Hopi culture through their clan oral traditions often cover hundreds of years, but small kinship units rarely survive the whims of fertility and mortality for more than a few generations. One of the most fascinating and celebrated pioneer study in this direction was that of Coming of Age in Samoa ${ }^{4}$ written in by Margaret Mead. This work traced the rites of passage associated with the transition from childhood to adulthood.After that a new method developed in archaeology related to the study of the ethnoarchaeological data known as Direct Historical Analogy. This type of analogy is applied when there is a temporal continuity between the archaeological culture and the ethnographic culture. It is generally considered to provide the highest probability of being correct. Such continuity is based either from historical records and description known as "area historical" or, based on field work in the area under consideration known as "area ethnographic model $^{5}$.

The Ethno archaeological study became popular from 1956 onwards when Maxime Kleindienst and Patty Jo Watson wrote Living Action Archaeology: The Archaeological Inventory of Living Community ${ }^{6}$. They laid emphasis on field investigation among living communities and to gather maximum necessary information. New theories emerged and one such important theory is General Comparative Analogy. This analogy is based mainly on the similarities between contemporary cultures and the cultural materials from an archaeological context. In such analogy, correlation between the two sets of cultures can be made on a crosscultural level without any special restriction ${ }^{7}$.This theory is applied by L.R Binford and said that our knowledge of the past is as good as our knowledge of present while writing ${ }^{8}$. 
Nunamiut: Ethnoarchaeology ${ }^{9}$ which addresses one of the oldest ethnic community in the world Alaskan Nunamiut Eskimo and their hunting camps, hunting stands, and residential sites. He tried to prove that Alaskan Eskimos today are actual predecessors of prehistoric communities in Alaska.

James F. O'Connell in his article Ethnoarchaeology Needs a General Theory of Behavior $^{10}$, defined ethnoarchaeology as the study of relationships between human behaviour and its material consequences in the present Practitioners hope to establish consistent links between the two that can be used to interpret archaeological evidence of human behaviour in the past. All these relevant studies aim to do exactly the recreation of past history by living among the ethnic community to integrate themselves without obstructing their activities and devote a considerable period of their lives to gather maximum data .

In India archaeologists realised the value of ethnographic data recently for the recreation of past history. India is a rich emporium of ethnic communities with different traditions and past ways of life.But D.D Kosambi recognized the utilization of ethnographic data from African or Australian tribes by the European archaeologists for establishing matriarchal or patriarchal relations existed in modern Europe. The culture of Indian ethnic communities like Khasis, Nagas, Asuras, Oraons, Bhils, Todas, Badagas, even today share the traits of past of past way of living. Kosambi stressed the relevance of multiplicity and variety of preserved traditions of ethnic communities in India like houses, grave goods, tools, utensils etc. helped to fill the gap between prehistory and present history. $\mathrm{He}$ is of the opinion that the social clusters that survive even in the heart of fully developed areas, say in and around cities, with others which mark all strata of a caste society as having developed at some older date from the absorption of tribal groups constitute priceless evidence for the interpretation of some ancient record or archaeological find; their survival as backward groups also furnish the real problems for explanation in the light of historical 
development ${ }^{11}$. The ethnoarchaeology has not yet been accepted as an important branch of archaeology and ethnographic data is rarely used for explaining archaeological evidences in India even today.

The scope for ethnoarchaeology Kerala is still pertinent because the prehistory of Kerala is still an enigma and it is a land of 36 divergent ethnic communities and most of them are noted for their archaic ways of life even today. Though acculturationis keenly visible among the most of the ethnic communities of Kerala but ethnic communities retain traits of pre-historic ways of living. Archaeological recording of the rich ethnic traditions preserved in the form of religious beliefs, folk songs, folk dance, folk stories, agricultural and cattle rearing practices, handicrafts, tool making, weaving, fishing technology, family life of this surviving communities are of great use for extracting information about prehistory of Kerala and about the past communities.

It is high time that we look at tribal culture from ethnoarchaeological perspectives and raise new questions such as who are tribes and who are not; the connection between tribalism and megalithism, and tribal religion as representing the earliest form of organized religion. We have also to examine the social roles played by funeral customs in a tribal society, the nature of social and gender relations existing in the tribal environment, and the historical factors behind tribal backwardness, etc. The study seeks to explore, among other things, the political and social organization, cultural traditions, funeral customs and megalithic practices of the tribe, historical roots of the tradition and practices of the tribe, the archaeological remains of their settlement sites and burial grounds, anthropological traits such as social institutions and cultural practices, and the origin myths encapsulated in folk traditions.

There are very few ethnoarchaeological studies on archaic communities of Kerala especially ethinic communities in the remote areas of Idukki district, Palaghat district, Nilambur ranges and Wyanad district like Mannan, Muduvan Kurumba, Muduga, 
Cholanaikkan, UraliKuruman, Kattunaikkan. Because of the insular nature of the settlements (dense forests; distance of about 20 to 30 kilometers between settlements), fieldwork among them is extremely difficult. (The nearest town from the nearest settlement is about 20 kilometers away). Moreover, they are exceptionally particular in keeping their tribal exclusivity and cultural identity and hence are hesitant to entertain outsiders. Their modes of subsistence (a combination of food gathering, cattle rearing, shifting cultivation and hunting) provide them sufficient resources to support themselves. Hence, they restrict their contacts with the outer world to the bare minimum and hence appear 'primitive' and 'savage' to the public.

Leaving aside the mystery and 'wilderness' that shroud their ${ }^{12}$ life, a $n$ ethnoarchaeological study of the tribe is exceptionally important for several reasons. First, their rich cultural and tribal tradition has to be unfolded. They have a dynamic system of social and political organization which has special relevance in the present ideological context of 'think globally, act locally'. They practice a highly effective system of ethnomedicine about which we know very little. Secondly, a study of the religious beliefs would throw light on the nature of early religious practices which anthropologists have variously described as 'primitive religion, 'animism', etc. Though a slow process of acculturation (or 'sanskritization') has started developing among them in recent times, they still follow a religion the predominant features of which are the worship of spirits, mountain peaks, trees, and stones with the exclusion of idol worship or the worship of gods and goddesses. Tribal religion is far separated from Hinduism and hence tribal people do not become a part of the traditional Hindu social structure. Thirdly community like Kurumba is the only tribe in Kerala who follow secondary funeral and the megalithic tradition. Fourthly tribal communities facing threats of physical extinction. Encroachments from the plains, large 'developmental' projects, government forest policies, increasing deforestation, and the 
rapidly shrinking tribal landscape have brought the tribal people to fight for their survival. Increasing acculturation and threats of physical elimination creates concern among social scientists because with the disappearance of a tribe, their rich cultural heritage also would perish. The distinguishing features of the culture have to be studied and recorded for the benefit of the future generations 


\section{References}

Christopher Catling, Archaeology Step by Step, Anness Publishing Ltd, London, P.226.

Peter Drewett -Field Archaeology an Introduction, $2^{\text {nd }}$ edition, Routledge, London, 2011, p.156.

Jess Fewkes, Tusayan migration tradition, Bureau of American Ethnology, Annual Report. No. 19., Washington, 1900, pp.577-633

Margaret Mead, Coming of Age in Samoa, William Morrow\& Co.New York,1928

Julian Steward, "The Direct Historical Approach to Archaeology", American Antiquity, Vol.7, Society for American Archaeology ,U.S.A,1942, pp.337-343.

Maxime Kleindienst and Patty Jo Watson, Living Action Archaeology: The Archaeological Inventory of Living Community, Anthropology Tomorrow 5(1),Routledge,London,1956, pp.75-78.

K.C.Chang, Major aspects of Interrelationship of Archaeology and Ethnology, Current Anthropology, Volume 8 No.3, 1967, p.232.

S.R Binford and L.R Binford, New Perspectives in Archaeology, Aldine Pub. Co , Chicago,1968,p. 268.

L.R . Binford, Nunamiut: Ethnoarchaeology, Academic Press, New York,1978.

James F. O'Connell, Ethnoarchaeology Needs a General Theory of Behavior, Journal of Archaeological Research, Vol. 3, No. 3 (September),Springer, U.S.A, 1995,pp. 205255.

D.D Kosambi ,An Introduction to the study of Indian History, Revised $2^{\text {nd }}$ edition Popular Prakashan,Bombay,1975,pp.7-8. 
